\title{
INSURANCE OFFER AND THE REASON FOR THE UNDERDEVELOPED MARKET IN SERBIA
}

\author{
Milorad K. Pušara \\ Belgrade Business and Arts Academy of Applied Studies \\ milorad.pusara@bbs.edu.rs
}

\section{Original Scientific Paper 10.5937/jouproman8-28661}

\begin{abstract}
This paper presents the current condition of the insurance market by creating an unpretentious review and pointing to the current deficiency of the insurance system in Serbia. It outlines some ideas that might solve certain issues and improve the current situation. Referred innovations that were introduced last year in the world market are very useful and can also serve as a good standard for joining the global insurance. Last but not least, the paper addresses the segment of insurance frauds as alarming incidences in need of attention.
\end{abstract}

If we consider the "Basic Elements of Insurance", risk, premium, and indemnity, and if we follow the development of the insurance throughout the world, we recognize that technology development and reduced business costs imply greater risks, a growing range of new products, decreased premium, and stimulating increase of the Indemnity. This leads us to the conclusion that we must enter the race with the developed countries and accept the way of their business management by following the latest innovations in the insurance market in order to be competitive and competent.

Key words: insurance market, disadvantages, innovations, basic elements of insurance competitiveness, quality.

\section{The reason for the underdeveloped market}

A justifiable reason for the skepticism of the population towards insurance proposals and a reason for the underdeveloped insurance market in Serbia can be partially found in the course of development of insurance itself. We are all familiar with the $50 \mathrm{~s}$ and $60 \mathrm{~s}$ of the last century, marked by the state domination, privatization, various machinations, manipulations and insurance company frauds. At the same time, we witnessed policyholders committing various frauds such as attempting to simulate insured events with intention of claiming undeserved indemnity.

All of the above has led to a situation we find ourselves in today - having an underdeveloped insurance market, but with a great potential and predisposition if we were to properly encourages development of a collective consciousness and regain people's trust.

If we consider the "Basic Elements of Insurance", risk, premium, and indemnity, and if we follow the development of the insurance throughout the world, we recognize that technology development and reduced business costs imply greater risks, a growing range of new products, decreased premium, and stimulating increase of the indemnity. This leads us to the conclusion that we must enter the race with the developed countries and accept the way of their business management by following the latest innovations in the insurance market in order to be competitive and competent. 
Audit and control of insurance companies should be conducted more often and more thoroughly, without any indications of corruption. Marketing divisions should be lead by trained and certified professionals, as oppose to the charlatans and unqualified individuals in charge of them up until now. We will refrain myself from mentioning the names of the companies in question, for we are certain they will know who we are talking about, as we are certain that a large part of the population will remember the period in question. In a most aggressive and least marketing professional way they attempted to persuade and force people into becoming their clients by constantly harassing them with their telephone calls. It was extremely difficult to defend oneself from such a pressure and people simply feared their phone calls.

Managers should necessarily be not only well trained, but with a vast professional experience behind them as well before they gain the trust of an insurance company. We see numerous examples of foreign companies, not only in the insurance industry but within the wider economy framework as well, posing the hiring of their managers as a prerequisite for investing in our market. The lack of trust in our ' 'experts", as we have seen so far (and we are talking only about some big insurance companies) is justified. The insurance companies should be teaming up with educational, higher education and academic institutions through ',Dual education", that is providing students with as much practice and courses possible, so that they could count on having a secure job immediately after completing their studies and be able to engage in any work process required by those institutions. In this way, we would obtain qualified and trained personnel, improve and speed up the development of our economy, and help in making first steps towards reducing "'brain drain".

By taking just a look at the innovations introduced in the insurance sector at the beginning of 2018. we can see where we stand in comparison to the leading countries. That should be our prime goal.

We will mention some of the more important innovations and quote a passage from the "Insurance" magazine published by 'Dunav osiguranje", company by author Dragomir Jovičić.

\section{Challenges and the course of development of modern insurance}

\subsection{Innovations in the world of insurance}

\subsubsection{Novelties in the insurance market worldwide -'Lemonade"'}

„Lemonade Insurance Company" is an insurance company founded in 2016. that specializes in property and accident insurance. Its service "Lemonade" was introduced on 21 September 2016. and has already become a hit in USA.

Initially, "Lemonade" offered insurance policies (apartment insurance, apartment property insurance, apartment owner and family members' accident insurance) only for the apartments situated in New York, but as of January 2017. it went nationwide, meaning it is now possible to arrange insurance coverage for any apartment across the USA. 
Insurance is provided via mobile device (iOS or Android) or computer (over www.network). The entire process of filing for an insurance is led by an intuitive programme, which provides the future policyholder with a complete list of risks covered along with their individual price, shortly before payment is made, thus allowing the policyholder to revise the policy coverage and price before the actual payment is made.

When the client is satisfied with the complete coverage and the given policy draft, payment is made via credit or debit card (online as well), after which the insured receives the Insurance terms and conditions and Insurance policy in an electronic form via e-mail. Damage claim is filed over the world wide web as well.

The novelty lies in the fact that the client is required to record a short video as a damage claim which is sent to be assessed by artificial intelligence AI, which then evaluates whether the client has been honest when reporting the damage. How this process of damage claim evaluation by artificial intelligence functions remains a business secret of "Lemonade" company.

In case a further evaluation is required, the damage is forwarded to a damage analyst and if all the conditions are met, indemnity is payed instantly, via Internet as well. The insurer "Lemonade" holds a record of three seconds (yes, we are talking about THREE SECONDS!) in time needed to review, approve and transfer the money to the policyholders account from the moment a claim has been filed (promptness in resolving claims).

That is a time record incomprehensible to any traditional insurance company worldwide however modernised and advanced it is. However, record time of three seconds is achievable (and beatable) but only if we are talking about time that elapses from the moment of filing a complaint to the moment a damage complaint is rejected.

"Lemonade's" business model has differed from the very beginning from that of typical insurance companies. From the amount payed on account of insurance premiums $20 \%$ is kept as a flat fee for business expenses. Nearly $20 \%$ is given to purchase reinsurance from the renowned world insurance companies, and another $20 \%$ goes to its own fund 'Lemonade Reinsurance'. The remaining $40 \%$ of premiums constitutes reserves that are returned to its"'Giveback" fund and are meant to be used for damage claims.

More precisely, if there were no damage claims filed during a whole year, the entire amount of $40 \%$ of unclaimed premiums would be given to a common cause of the users' choosing. When signing up for an insurance policy every client is allowed to choose a charity fund to which he would like the money from the unclaimed premiums to be transferred at the end of the year. This feature represents an additional incentive for potential clients to choose exactly this company as their insurer.

"Lemonade" operates with an extremely low average premium price of only 5 dollars a month for personal property coverage or 50 dollars a month for an entire apartment insurance. Such a price is in average six times lower compared to any other leading domestic insurance company („Allstae“, „State Farm“, „Liberty „Mutual“, „Farmers“), and as such poses an enormous obstacle to the business of existing traditional insurers on the market. 
Management of „Lemonade“ prides itself in being able to offer such low insurance rates for which it gives credit to less paperwork, less administrative costs and less insurance agent costs. Will the whole project be able to retain such low prices in the future as well remains to be seen, but one should keep in mind the market expansion to the entire USA, as well as a complete risk coverage with quality reinsurance.

\subsubsection{On-demand hourly drone insurance -,verifly“}

-,,Global Aerospace“-

Expansion in development of drones and beginning of their mass use worldwide has created a need for a third-party liability insurance, regulated by law as mandatory in many world countries.

The need for drone insurance to be delivered on-demand wherever its users are was recognized by the insurance company "Global Aerospace'. 'Global Aerospace" is a global insurance company which specializes in aviation insurance. It was founded in January 2001. following the merger of two leading specialist aerospace insurance Pools, the British Aviation Insurance Group (BAIG) in the UK and Associated Aviation Underwriters (AAU) in the USA.

A few years ago they launched an android app ' 'Verifly', which provides users with instant third-party liability insurance in the amount of up to $\$ 1.000 .000$ of liability cover for as little as $\$ 10$ per hour.

The app combines mapping technology and real-time conditions to advise unmanned aerial systems (UAS) users of potential flying risks during the flight. Insurance premium payment and approval are enabled instantly via previously registered credit card.

\subsubsection{AI (artificial intelligence)}

-Artificial intelligence in japanese insurance companies -

The japanese insurance company 'Fukoku Mutual Life Insuranc', has laid off 34 employees and replaced them with an artificial intelligence (AI) system that can calculate insurance payouts in hope it will increase productivity by $30 \%$.

The system is based on IBM Japan Ltd's Watson, which IBM calls a "cognitive technology that can think like a human" and which calculates the amounts needed to be payed to clients by the company.

Each and every one of those 34 employees, most of which have had a five-year work contract, had been fired by the end of March 2017.

The entire process from application, to liquidation and final payment is automated and completed by cognitive technology without presence of office employees. The program in question has cost "Fukoku", 2.36 million dollars for set-up and around 177.000 dollars a year for annual maintenance, but has instead saved the insurer around 1.65 million dollars worth of employee salaries.

This means that the 'Fukoku Life', will have made return on invested capital in two years time from its implementation. Some other japanese insurance companies have already began with the implementation of similar technologies. ',Dai-ichi Life Insurance', deploys Watson system for processing of estimated payment, while 'Nippon Life Insurance"' began using AI system for making the best coverage plan for its individual clients. 


\subsubsection{AIA and insurance sale over tablet (Tablet Sales Toolkit)}

AIA Group is a panasian insurance company principally engaged in the provision of life insurance. The Company operates in 18 countries throughout Asia and Pacific. Its first tablet application was launched back in 2011.

Shortly afterwards, the Group recognized the importance of tablet use with its AIA advisors and it created a special team that would continue to work on further development of the service. The team revised the complete service architecture guided by three main principles: completely paperless, without interruption of sales process anywhere and anytime, and a concluded deal with client after only one meeting.

In the first quarter of 2013. three other countries began implementing the service (Singapore, Malaysia i Indonesia), whilst the implementation in the remaining six countries began at the end of 2013. This is a complete end-to-end product, from introduction with a client to issuing the policy.

As soon as it was launched the project was a great success. It is estimated that in some countries it reached a production of $80 \%$ of all issued policies after only 12 months from its introduction. Implementation of this product brought to the light its numerous benefits, among which the most important are the following:

- client gets an impression that sales advisor is more professional and more trustworthy

- the deal is concluded without any paperwork, with most policies being issued on the spot
- the absence of ping-pong effect between agent and underwriter, i.e. less visits to client are required and agents are more productive

- a motivational boost on behalf of agents is noticeable, i.e. agents feel proud to be part of the AIA group since it posseses the most advanced tablet technology on the market

- there is less work for underwriters and fewer infrastructural conditions

- printing costs of policies, as well as of marketing material, are reduced, there is no scanning, archiving, filling out printed questionnaires, the costs of shipping fee and courier are eliminated.

- tablets are less expensive than laptops

- agents conclude deals faster and are more productive than before

It is evident that the use of tablets in the insurance sales business has brought AIA company an enormous success, not only locally, in its home country, but across countries of the region as well. Furthermore, this taking over of large part of clients from the competition happened rather quickly, as things usually do in the IT world. It remains to be seen how the competition from the region will react to these new business technologies, but in any case, the reaction is inevitable, and will happen soon.

The direction in which the Asian insurance market is moving is best illustrated by the conference "The Digital Insurer's inaugural Asia 2016" held on 23 November 2016. in Hong Kong, at which the future of the insurance market was presented by Sophia, a "Hanson Robotics" company humanoid robot. 
It is obvious that technological development worldwide is happening at an ever faster pace bringing numerous innovations along with it, and improving and speeding up the way business is done. New technologies affect all spheres of our lives on a daily basis, beginning with the agriculture, to industry, tourism, transport, and all the way to our field of interest insurance.

Examples of innovations in the insurance sphere are numerous, but presented here are but a few examples sufficient to lead to certain conclusions as to in which direction the insurance industry is going.

The first conclusion is that the focus of insurance is currently shifting from Europe and London, as the cradle of insurance, to North America and Asia. It is obvious that resting on old laurels and a large concentration of capital at this moment are not enough to maintain the primacy on the global insurance map.

The insurance market in Europe (UK and Germany) is too conservative and concentrated on already established business systems. On the other hand, new business ideas and technologies are emerging in North America and Asia.

Here we do not see the impact of Brexit on the final outcome of the shift in the focus of insurance. Whether Lloyd's bell is moving to New York or Singapore remains to be seen.

Another conclusion would be that in the future, all insurance companies will use information technologies on an increasing scale, even to the level of complete automation of the business process. Companies that do not switch to this type of business will slowly shut down and disappear.

The need for labor, after all, as in other branches of the economy, will be reduced over time. Serious audit firms estimate that, given the business automation, we can expect unemployment in the world to reach 60 percent in approximately 25 years time. There will be no talk about these predictions, the global impact of new technologies on employment and the problems that the governments of various world countries and the world population will face in this paper.

It is quite certain that the automation of the insurance process in the near future, in addition to the already presented examples of life insurance in Asia and home insurance (real estate) in the US, will be extended to other types of insurance, such as insurance of vehicles, planes, ships (personal property), business liability insurance, agricultural insurance, and why not, to insurance that falls into the category of compulsory insurance.

Many countries around the world are fighting against globalization and the arrival of various global companies such as "PayPal", "Amazon", "Uber", "Taxify", which leave their budgets increasingly empty $^{2}$.

It is only a matter of time before a global insurance company appears that would unite all these things into a whole and enable the provision of insurance coverage for certain/all types of insurance at all points on the globe. The process of automation and globalization of everything is unstoppable, the only question left is how we will cope in the times to come. 


\section{Insurance frauds}

We will look at the concept of insurance fraud from a legal and economic aspect, a scheme which contributed to the current situation in our country. Insurance fraud is any act committed to obtain financial benefit or advantage from an insurance company by staging a loss, an accident, or falsifying information when filing a claim for insurance indemnity.

What these definitions have in common is that they mainly treat the so-called external frauds, i.e. frauds directed against the insurer, i.e. to his detriment. On the other hand, there is a category of internal fraud that refers to fraud in the "insurance industry" itself, and includes bribing insurance company employees, misrepresentation of facts by employees, i.e. directors, agents, brokers or insurance intermediaries in order to gain personal benefit or prevent the official regulatory authorities from taking certain actions.

Broadly speaking, the insurance company itself, i.e. its owners, can be perpetrators of insurance fraud, usually on a larger scale, when premium income is misused for personal gain or some other purpose outside the insurance function without fulfilling obligations to policyholders.

Some of the most common types of insurance fraud are:

- Providing incorrect information by the insured / policyholder at the conclusion of the contract that affects the risk assessment or acceptance of insurance

- $\quad$ Staging a traffic accident in order to cover some previous damage.
- $\quad$ False theft of vehicles and other means of transport

- $\quad$ Fake traffic accidents with a "run away" vehicle.

- $\quad$ Exaggeration of injuries of persons involved in traffic accidents.

- $\quad$ Fake burglaries, thefts or arson at home or at work and exaggeration of the value and quantity of stolen or burned items.

- Falsification of evidence by an official or "insider" within an insurance company.

- Fraud based on identity theft (credit cards, loans ...).

- $\quad$ Selling fake insurance.

- $\quad$ Cases where the insurance agent retains the premium paid.

- When an insurance agent sells coverage to the insured for risks that he did not ask for under the pretense that they are part of a "package".

- In the case of health insurance by supplying false medical bills and stating false medical history (also applies to life insurance).

When a question is posed, who ultimately pays for these frauds, the answer is mostly policyholders who pay higher insurance premiums to cover the mentioned expenses of the insurance provider. 


\subsection{How fraud is committed in Serbia}

There is no institutional monitoring of this type of crime in Serbia, so we do not even have official data on the number and amount of falsified damages. It is only certain that the percentage of false damages in Serbia is much higher in comparison to developed countries.

Insurance frauds are for the most part recorded in the domain of compulsory motor third party liability insurance. It is thee valuation of the insurance industry that the number of false claims for damages on vehicles in Serbia ranges from $30 \%$ to $40 \%$.

The most common frauds can generally be grouped into:

- Pre-arranged vehicle damages where a vehicle with a low residual value (e.g. 20 year old "Yugo") hits an expensive new vehicle, usually with foreign license plates. This usually happens at night on side roads or in areas with no cameras, of course during weekends. The foreign vehicle returns to the country of origin, and then issues a claim with false invoices for the repair costs, which usually exceed $€ 10.000$.

- An attempt by car owner to take the opportunity to incorporate a whole range of previous minor damages to the vehicle into the garage bill associated with the real accident.

- A particular problem poses exaggeration of bodily injuries in car accidents, which are difficult to prove, such as twitching injuries of the neck, the so-called "Whiplash" injury that cannot be seen on Xray.
The phenomenon is the city of Novi Sad, where an unusually large number of people being in a vehicle at the time of collision and with these exact types of injuries has been reported in comparison to other cities in Serbia. Also unusual is the number of passengers reported in the vehicle at the time of the collision - minimum three ${ }^{2}$.

There are more cases by the day in which agencies, lawyers and doctors offer injured persons smaller "damage compensation" only to later collect significantly higher insured amounts through the court.

The most common cases are with all-risk insurance, where the damage is reported a day later, as damage caused in the parking lot by unidentified persons. This usually happens when the driver was intoxicated and did not call the police because he was aware that in such a case the damage would not be accepted for coverage by the insurer. It is often the case that a leased vehicle is stolen or an attempt is made to get an already damaged vehicle covered with an all-risk policy.

In terms of number of frauds, non-life insurance is not lagging behind either, where fires in office buildings and warehouses are faked. Then there is burglary, where the reported stolen goods are sold on the black market and duly collected from the insurer.

The most drastic example is that from a few years ago, when one of the insured companies tried to collect damages in worth of astonishing 2.3 million euroson behalf of burglary from the "Delta Generali" insurance. Everything had been planned so carefully to the extent that the preparation alone took them 13 months and during that time over $€ 300.000$ was invested. 
Due to all these forms of fraud, insurance companies are hiring and increasingly investing in highly competent and experienced staff in the form of experts, assessors, and inspectors who are very perceptive and quick to detect such frauds.

Many are optimistic about their forecasts for the insurance market for the insurance is exceeding national borders more and more by the day. The UN has supported the International Chamber of Commerce in Paris in establishing the International Maritime Bureau (IBM), designed to combat foreign trade fraud. There is also a lot of pressure on insurers to include risk of virus attacks on computers that cause huge damages in their policy coverage.

\section{References}

1. Avdalović, V.\& Petrović E., (2016). Rizici $u$ osiguranju [Insurance risks], Niš: The Faculty of Economics in Niš.

2. Grujić, R. (2007-2008). Osiguranje, teorija - zakonodavstvo - praksa
[Insurance, theory - legislation - practice]. Belgrade.

3. Jovanović, O. S., (2018) "Izazovi pravnog regulisanja robota $i$ osiguranja od šteta prouzrokovanih njihovom upotrebom" ["Challenges of legal regulation of robots and insurance against damages caused by their use'']. "Tokovi osiguranja". 3, 81.

4. Jovičić, D. (2017). "Da li je budućnost baš tako daleko?- Inovacije u svetu osiguranja"[' 'Is the future really that far? - Innovations in the world of insurance'']. "OSIGURANJE". Vol. 367/2017, XLV ISSN 1452-5755, p.45.

5. Kočović, J. \& Jovović, M. (2016). „Uticaj liberalizacije $i$ privatizacije na razvoj tržišta osiguranja u Srbiji " ["The impact of liberalization and privatization on the development of the insurance market in Serbia']. 'Tokovi osiguranja', 1.

6. Pak, J. (2004). „Pravna zaštita korisnika usluga osiguranja “['Legal protection of the insurance policy holders'']. Privreda $i$ pravo u tranziciji.

7. Petrović, R.S. \& Stojanović, R.M., (2012)"Prevare u osiguranju"["Insurance frauds"']. "Tokovi osiguranja". 1, 50.

8. Žarković, N. (2013).' Pojmovnik osiguranja, , ['Insurance 